\title{
EROTISMO E SEXUALIDADE: A (DES)CONSTRUÇÃO DO FEMININO AO LONGO DE UM SÉCULO
}

Samantha Costa de Sousa é formada em Letras pela UEPA. Atualmente, é aluna do Mestrado em Estudos Literários pela UFPA e do curso de Especialização Lato Sensu em Psicopedagogia Institucional pela FAEL. Atua como professora de Língua Portuguesa, Redação e Literatura no Instituto IEPA-Igarapé-Açu.

E-mail: Samantha.c.sousa@gmail.com

\section{Resumo}

A partir de uma análise sociocultural, estudouse neste artigo a construção de três personagens femininas da literatura brasileira, cada uma representando uma maneira de transgredir os valores morais de sua época, e consequentemente sendo julgadas pela sociedade na qual se encontram. As obras selecionadas foram Lucíola (2009), de José de Alencar, A Carne (2002), de Júlio Ribeiro e Contos d'escárnio - Textos Grotescos (2002), da Hilda Hilst.

\begin{abstract}
Through a socio-cultural analysis, we studied in this paper the construction of three female characters in brazilian literature, each representing a way to transgress the moral values of his time, and consequently being judged by society in which it is. The selected works were Lucíola (2009), by José de Alencar, A Carne (2002), by Julio Ribeiro and Contos d'escárnio - Textos Grotescos (2002), Hilda Hilst.
\end{abstract}

\section{1) Introdução}

Durante séculos, a sociedade se baseou num sistema patriarcal, no qual a mulher figurava como submissa e inferior ao homem. A ela já fora negado o direito de estudar, de escolher o próprio esposo, de circular em locais públicos, e a ela estava reservada apenas a vida doméstica e a maternidade. Obviamente, tudo isso mudou com o passar dos anos e com muita luta, foi uma transformação lenta e contínua que ainda não se encerrou. Há muito o que se discutir quando o assunto é a história das mulheres na sociedade brasileira, mas há um assunto em específico que pretendo abordar neste artigo, que foi por muito tempo silenciado e (moral e legalmente) proibido: a liberdade sexual entre as mulheres. Farei esta discussão abarcando um século de mudanças importantes na História e através de três retratos da sociedade brasileira, as obras Lucíola (1862), de José de Alencar, A Carne (1888), de Júlio Ribeiro e Contos D'escárnio - Textos Grotescos (1990), de Hilda Hilst.

$\mathrm{O}$ que as três obras têm em comum? Abordam personagens femininas transgressoras para suas épocas, personagens que são exatamente o que não se espera que uma mulher seja. Lúcia, apesar de ser uma heroína romântica, é uma prostituta. Lenita, como um produto das experiências do Naturalismo, é pervertida. Clódia, representante da contemporaneidade, rompe qualquer tabu ainda existente no final do século XX, é artista, independente, bissexual e fascinada por tudo o que se refere ao sexo. Cada uma, a sua maneira, foge às regras morais que regem a sociedade, e por esta são julgadas. Veremos, doravante, que entre História e ficção há um elo inevitável, esta se transpõe naquela, uma dá sua voz para a outra.

\section{2) O "ser mulher" entre os séculos XIX e XX}

Por muito tempo falar sobre sexualidade era algo proibido. A sociedade fundada sob a moral cristã via na atividade sexual apenas um meio para a procriação, qualquer ato que se desviasse desta função seria interpretado como um pecado, uma corrupção da carne e do espírito. Várias eram as providências que se tomavam a fim de evitar atos libidinosos, pois se acreditava que o desejo sexual era o responsável por diversos males físicos e psicológicos, aliás, o próprio desejo sexual era visto como uma doença que precisava ser tratada e controlada. 
Os séculos XVIII e XIX, entretanto, favoreceram certa abertura ao assunto. Pesquisas especializadas foram dirigidas pelos estudiosos da época, e o que se buscava não era uma teoria geral sobre a sexualidade. Falava-se sobre sexo em "forma de análise, contabilidade, de classificação e de especificação, através de pesquisas quantitativas e causais" (FOULCAULT, 1988, p. 26-27). Entretanto, o assunto ainda era discutido com muita cautela para que os estudiosos não perdessem a credibilidade diante da sociedade, falar sobre sexo ainda causava certa aversão. Nas palavras de Condorcet (apud FOUCAULT, 1988, p. 27): "raramente os filósofos encararam com segurança tais objetos situados entre a repugnância e o ridículo, em relações às quais seria preciso, ao mesmo tempo, evitar a hipocrisia e o escândalo". Até mesmo a medicina hesitava entrar neste campo: "A sombra que envolve esses fatos, a vergonha e a repugnância que eles inspiram, sempre afastaram o olhar dos observadores... durante muito tempo hesitei em introduzir neste assunto o quadro repulsivo" (TARDIEU apud FOUCAULT, 1988, p. 27).

Porém, apesar da perplexidade diante do assunto, muitos pesquisadores de diversos campos, não apenas da medicina, demonstraram interesse em estudá-lo. É o que aponta Foucault:

Inicialmente, a medicina, por intermédio das "doenças dos nervos", em seguida a psiquiatria, quando começa a procurar - do lado da "extravagância", depois do onanismo, mais tarde da insatisfação e das "fraudes contra a procriação", a etiologia das doenças mentais e, sobretudo, quando anexa ao seu domínio exclusivo, o conjunto das perversões sexuais; também a justiça penal que por muito tempo ocupou-se da sexualidade, sobretudo sob a forma de crimes "crapulosos" e antinaturais, mas que, aproximadamente na metade do século XIX se abriu à jurisdição miúda de pequenos atentados, dos ultrajes de pouca monta, das perversões sem importância, enfim, todos esses controles sociais que se desenvolveram no final do século passado e filtram a sexualidade dos casais, dos pais e dos filhos, dos adolescentes perigosos e em perigo tratando de proteger, separar e prevenir, assinalando perigos em toda parte, despertando as atenções, solicitando diagnósticos, acumulando relatórios, organizando terapêuticas. (1988, p. 32-33)

A razão que levou estes estudiosos a se preocuparem com o comportamento sexual dos indivíduos girava em torno da ordem e da moral, motivos que os levava a produzir seus discursos voltados para um alerta dos perigos que uma vida sexual poderia provocar àqueles que a ela se submetem sem os devidos cuidados. Em todos os casos, para se ter uma vida saudável, a castidade era sempre a melhor escolha, assim se evitavam "furores" e outros males que poderiam prejudicar a saúde física e mental dos indivíduos.

Uma vida casta era um ideal pregado pela Igreja e pelo Estado e hipocritamente propagado pela sociedade. Se, por um lado, zelava-se pela família e pelos bons costumes, por outro, o adultério estava presente em todos os lugares, dentro das famílias pobres e das ricas, e até mesmo entre as famílias nobres. No Brasil não era raro encontrar prostitutas e famílias "ilegítimas", "teúdas e manteúdas", como eram chamadas as mulheres amantes de homens casados, proliferavam no Rio de Janeiro, a então capital do Brasil. Mary Del Priore mostra a impressão que os estrangeiros tinham do Brasil: 
Os viajantes que por aqui passaram na primeira metade do século XIX concordavam num ponto: "a moralidade reinante no Rio de Janeiro se apresenta bem precária", como dizia o mineralogista inglês Alexander Caldcleugh. Já o francês Freycinet queixava-se dos vícios e da libertinagem. Afinal, tratava-se de um país onde "não é difícil encontrarse todo o tipo de excessos". E seu conterrâneo Arago cravava: "o Rio era uma cidade onde os vícios da Europa abundavam”. (DEL PRIORE, 2011, p. 45)

A concubinagem era ilegal, obviamente, mas em muitos casos era tolerada, até mesmo pelas próprias esposas. A promiscuidade era um comportamento exclusivamente masculino, e por isso consentido, como algo que não se pudesse evitar, até mesmo a igreja admitia que os homens tinham necessidades sexuais, fazia parte da natureza masculina, o "mal passo" do homem era perdoável. Mas e quanto à mulher? Qual posição ela ocupava neste jogo de relações? Quando digo que a promiscuidade é um comportamento exclusivo aos homens, não significa que existiam apenas mulheres castas, ao contrário, havia muitas mulheres infiéis, mas estas pagavam pelo crime com a reclusão, com a desonra ou com a própria vida, uma vez que o Estado tolerava o assassinato da esposa adúltera.

Desde a tenra idade, as mulheres eram educadas para o casamento e para a maternidade, sua educação restringia-se ao aprendizado de tarefas domésticas, como cozinhar, costurar, bordar, algum conhecimento musical também era propiciado a elas, poucas eram alfabetizadas e no que diz respeito à própria sexualidade, eram tolhidas, $\mathrm{o}$ assunto era tabu e é muito provável que muitas não conhecessem nada sobre isso. A mulher era considerada, perante a igreja e perante o Estado, inferior ao homem em todos os sentidos. Sustentava-se, então a figura de uma mulher idealizada:

A mulher tinha que ser naturalmente frágil, bonita, sedutora, boa mãe, submissa e doce. As que revelassem atributos opostos seriam consideradas seres antinaturais. Partia-se do princípio de que, graças à natureza feminina, o instinto materno anulava o instinto sexual e, consequentemente, aquela que sentisse desejo ou prazer sexual seria inevitavelmente anormal. (Idem, p. 65)

A pureza era um ponto chave na educação feminina. A virgindade era essencial para um bom casamento, isso se explica pelo fato de que se acreditava que a jovem obedeceria melhor a quem a iniciasse. E mesmo depois de casadas, as mulheres não poderiam ceder aos seus impulsos sexuais, deveriam se espelhar na Virgem Maria e zelar pela castidade:

O culto da pureza que idealizava as mulheres reforçava a distância entre os casais. E não faltavam "conselhos" em toda parte: "Lembrai-vos também que ainda quando no quarto e leito conjugal se dispense o pudor, a castidade, contudo, é de rigoroso dever e conveniência, porque a mulher que se abandona a todos os caprichos e fantasias se faz desprezível aos olhos de sua própria consciência e aos de seu marido se ele não é um libertino e debochado" (Idem, p. 59).

O prazer no ato sexual não era consentido às mulheres, elas não podiam, tampouco, expressá-lo sem correr o risco de serem consideradas ninfomaníacas ou histéricas, aliás, era até uma questão de saúde evitar que a mulher chegasse ao orgasmo, 
pois, como indica Del Priore (2011), o prazer poderia levá-la a "excessos", o que detonaria os "furores uterinos". Assim, era responsabilidade do homem evitar a volúpia da esposa, o ato sexual deveria ser rápido e qualquer outro ato erótico era considerado indecoroso, até mesmo a nudez era proibida. Apesar de que entre os anos de 1840 e 1850 tenha se admitido um papel relevante do organismo feminino para a procriação, pois os médicos franceses Pouchet e Négrier descobrem o mecanismo de ovulação, a descoberta apenas fortaleceu a ideia de que o prazer feminino é dispensável. Se a ovulação era espontânea, a procriação era principalmente responsabilidade do homem, e este, diante desta áurea de santidade denotada ao casamento e dos deveres maritais, também não buscava o prazer na esposa. Quando o esposo se limitava aos preceitos morais da sociedade, abstinha-se do sexo, mas quando necessitava suprir os desejos da carne, encontrava o prazer entre prostitutas e amásias.

Este ideal de comportamento também é retratado pela literatura, às vezes em contemplação à heroína virginal, outras vezes nos deparamos com personagens que contrariam os preceitos morais e religiosos, e são exatamente estas que nos interessam nesta pesquisa, como já fora explicitado anteriormente. Agora que conhecemos o comportamento esperado e imposto para as mulheres desta época, cabe agora visualizar a (des)construção desse perfil feminino.

José de Alencar, em Lucíola, apresenta um misto da mulher idealizada e da mulher repreendida. A personagem Lúcia é construída a partir de um jogo paradoxal que confunde seu amante Paulo, levando-o a duvidar constantemente daquilo que Lúcia demonstra ser. $\mathrm{O}$ romance se encaixa no movimento romântico brasileiro, foi publicado pela primeira vez em 1862, causando nos leitores da época certo desconforto ao levar ao público uma temática considerada imoral, a prostituição. Segundo De Marco (1986), duras críticas e censuras já haviam sido desferidas a uma obra anterior, Asas de um Anjo, publicada em 1858, que tratava dessa mesma temática que Lucíola. A peça fora retirada de cartaz por uma ação policial por ser considerada indecorosa e por ir contra os preceitos morais da sociedade. Coincidindo com este fato, há uma pausa na produção do autor, a qual ele retorna aos poucos e com a mesma temática em Lucíola.

Entre uma obra e outra, o tempo e influências das produções europeias contribuíram para o aperfeiçoamento da discussão sobre um assunto tão delicado. Segundo Faria (1993, p. 184) "Alencar (...) tinha em mente conciliar a ideia romântica da regeneração da mulher perdida com a moralidade do teatro realista". O autor visava, na produção de sua obra, satisfazer dois princípios: naturalidade e moralidade (FARIA apud SILVA, 2006). O primeiro princípio brotava da influência "clássica, trazendo a tona a ideia horaciana da utilidade da arte" (Idem, p. 103), o segundo partia de uma contribuição "realista, de seu próprio tempo, contribuição de Alexandre Dumas Filho" (Idem, Ibidem).

Evidentemente, Alencar tinha uma preocupação moralizadora em suas obras, em defesa disto ele explicita no decorrer de um artigo publicado no Diário do Rio de Janeiro de 23 de junho de 1858 a sua ideia de moral: 
Será imoral uma obra que mostra o vício castigado pelo próprio vício; que tomando por base um fato infelizmente muito frequente na sociedade, deduz dele consequências terríveis que servem de punição não só aos seus autores principais, como àqueles que concorreram indiretamente para a sua realização?

"O vício castigado pelo próprio vício", eis o que conduz a narrativa de Lucíola. Para que isto se esclareça, convém que conheçamos seu enredo. Lúcia nos é apresentada já com um perfil paradoxal: "Ressumbrava na sua muda contemplação doce melancolia e não sei que laivos de tão ingênua castidade, que o meu olhar repousou calmo e sereno na mimosa aparição" (ALENCAR, 2009, p. 9), era assim que ela parecia a Paulo naquele primeiro instante, mas como uma máscara, este ar de castidade logo foi afastado por Sá, amigo de Paulo, que diante da indagação deste sobre quem seria aquela senhora, responde sarcasticamente: “- Não é uma senhora, Paulo! É uma mulher bonita. Queres conhecê-la?..." (Idem, ibidem). Paulo envergonha-se da ingenuidade por confundir "a máscara hipócrita do vício com o modesto recato da inocência" (Idem, Ibidem), observa então alguns detalhes importantes sobre aquela mulher que vislumbrava: ela estava só, sem a companhia de um pai, um marido ou um irmão, isso já seria o suficiente para levantar suspeitas sobre ela. Julgamentos preconceituosos são comuns no decorrer da obra, algo bem justificável diante dos preceitos ideológicos do século XIX. Lúcia era uma prostituta, estaria sempre à margem da sociedade, por mais que demonstrasse escrúpulos e pudor, sua condição tirava-lhe inclusive o direito de defender-se, é o que reflete Paulo na ocasião de se confundir novamente com este caráter dúbio da personagem:

Se eu amasse essa mulher, que via pela terceira ou quarta vez, teria certamente a coragem de falar-lhe do que sentia; se eu quisesse fingir um amor degradante, acharia força para mentir; mas tinha apenas sede de prazer, fazia dessa moça uma ideia talvez falsa; e receava seriamente que uma frase minha lhe doesse tanto mais, quanto ela não tinha nem o direito de indignar-se, nem o consolo que deve dar a consciência de uma virtude rígida. (Idem, p. 15)

Lúcia carrega consigo um mistério que confunde não apenas a Paulo, mas o próprio leitor se vê dividido entre uma Lúcia casta e pudica que treme, enrubesce, tornase lívida e se aflige diante das carícias do amante, e outra Lúcia que é sedutora e erotizada, que domina os homens e os têm para seus favores. Aliás, esta dualidade parece se revelar apenas a Paulo, pois a imagem que os demais amantes carregam de Lúcia é de uma mulher extravagante e impetuosa, dominadora, que nas palavras de Cunha:

É seu costume, num belo dia, sem causa, sem o mínimo pretexto, declara a um homem que suas relações estão acabadas; e não há o que fazer. Podem oferecer-lhe somas loucas, é tempo perdido. Também no dia seguinte, ou no mesmo, daí a uma hora, toma outro amante que não conhece, que nunca viu. (...) Há dias em que está de um humor insuportável: fica uma estátua, e não há forças humanas que possam arrancar daquela massa inerte um sorriso, uma palavra, um movimento. Se o homem não possui grande dose de paciência para sofrê-la calado, ela fecha-lhe a porta muito delicadamente, e manda-lhe dizer pela criada: "que tenha a bondade de deixa-la tranquila para todo o 
sempre'. E uma vez dito, não volta. (...) A Lúcia não admite que ninguém adquira direitos sobre ela. Façam-lhe as propostas mais brilhantes: sua casa é somente sua; ela $\mathrm{o}$ recebe sempre como hóspede; como dono, nunca. Na ocasião em que o senhor a toma por amante, ela previne-o de que reserva-se plena liberdade de fazer o que quiser e de deixa-lo quando lhe aprouver, sem explicações e sem pretextos, o que sucede invariavelmente antes de seis meses; está entendido que lhe concede o mesmo direito. (Idem, p. 27-28)

Só por esse quadro de características poderíamos dizer que Lúcia transgride um ideal de feminilidade patente no século XIX: é promíscua, quando deveria ser casta, dita as próprias regras, quando deveria ser submissa, domina os homens através daquilo que deveria ser reprimido. Lúcia torna-se desprezível aos olhos daquela sociedade não apenas pela profissão, mas pelas atitudes que contrariam tudo aquilo que era ensinado às mulheres. Aparentemente muito senhora de si, Lúcia é até mesmo comparada a Lúcifer, não é vista como uma mulher digna de confiança, tampouco como alguém a quem se possa amar ou como alguém capaz de amar. Paulo é alertado por Sá, mas encontra-se já completamente envolvido com Lúcia, embora envergonhado por isso. Numa das cenas, talvez a mais erótica da obra, Lúcia exibe-se diante de um pequeno público formado por Sá, Couto, Rochinha, Paulo e três mulheres que os acompanhavam. Mesmo diante do pedido de Paulo, Lúcia, num espetáculo de sensualidade, despe-se e imita a posição das lascivas pinturas da sala de Sá. Paulo indignou-se perante a cena, era algo demasiado imoral para ser perdoado, até mesmo a uma prostituta:

Quando a mulher se desnuda para o prazer, os olhos do amante a vestem de um fluido que cega; quando a mulher se desnuda para a arte, a inspiração a transporta a mundos ideais, onde a matéria se depara ao hálito de Deus; quando, porém, a mulher se desnuda para cevar, mesmo com a vista, a concupiscência de muitos, há nisto uma profanação da beleza e da criatura humana, que não tem nome.

É mais do que prostituição: é a brutalidade da jumenta ciosa que se precipita pelo campo, mordendo os cavalos para despertar-lhes o tardo apetite. (Idem, p. 46)

Este poderia ser o ato maior de expressar sua liberdade, se não fosse o momento em que a personagem nos revela que ela mesma se despreza por ser o que é e por fazer o que faz, Lúcia sente vergonha de servir aos prazeres dos homens, sente-se sem valor algum. De acordo com Pinto (1999, p.100), Lúcia acha a prostituição "cousa sórdida e abjeta", como ela nos revela mais adiante:

Eu tinha-me vendido a todos os caprichos e extravagâncias; deixara-me arrastar ao mais profundo abismo da depravação; contudo, quando entrava em mim, na solidão de minha vida íntima, sentia que eu não era uma cortesã como aquelas que me cercavam. Os homens que se chamavam meus amantes valiam menos para mim do que um animal; às vezes tinha-lhes asco e nojo. Ficaram gravados no meu coração como germes da virtude... Essa palavra é uma profanação nos meus lábios, mas não sei outra. Havia no meu coração germes da virtude que eu não podia arrancar, e que ainda nos excessos do vício não me deixavam cometer uma ação vil. (ALENCAR, 2009, p. 130-131)

A partir de então começa a se operar em Lúcia uma transformação, ela enfim se rende ao amor que sente por Paulo, e através dele purificava-se aos poucos das máculas 
de sua vida imoral. Trazia consigo uma aparência recatada, cheia de pudor, sua volúpia parecia definhar, abandonou a vida libertina para dedicar-se exclusivamente a Paulo, tornou-se submissa a ele e, contrariando o que Cunha dissera a seu respeito, deu a Paulo o direito de dono da sua casa. Observamos, então, o processo de redenção de Lúcia através do amor puro, o amor romântico. Reafirmando a ideia de José de Alencar sobre a moral, Lucíola não é uma obra que exalta a vida mundana, ao contrário. A transgressão de Lúcia, longe de parecer um exercício de reconceituação do feminino, é mais uma demonstração de que o que está errado deve ser abandonado e corrigido. A personagem caminha para a direção do apaziguamento para com a sociedade, entretanto, o caminho que tomara anteriormente não tem volta. Numa sociedade patriarcal do século XIX não há como perdoar e ignorar um crime contra a moralidade.

Por mais que Paulo e Lúcia se amassem, a sombra da desconfiança e do preconceito sempre paira sobre eles. Momentos de paz são interrompidos pelos ciúmes constantes de Paulo, pois ele sempre espera de Lúcia a mentira e a traição, enquanto que Lúcia luta para convencê-lo da pureza de seus sentimentos, da virgindade espiritual que conserva consigo. Mesmo diante da afronta de Paulo, ele segue adiante na sua transformação, desfaz-se das roupas caras, das joias, vende sua casa da cidade e compra uma casa simples afastada do núcleo urbano, abstém-se do sexo e nos revela a outra que tem guardada dentro de si, a Maria da Glória, seu verdadeiro nome. Relembra então o tempo em que era assim chamada, quando teve de se vender pela primeira vez, aos quatorze anos, para poder salvar a vida da família, e que por causa disso fora expulsa de casa pelo pai, tendo de se submeter a uma vida desonrada e marginal. Isso seria o suficiente para assinalar a inocência de Lúcia? Para ser perdoada por Paulo, talvez. Mas jamais seria perdoada pela sociedade, nem mesmo por ela própria. Lúcia considera-se indigna do amor de Paulo e jamais poderia recebê-lo como esposo.

Mesmo afastada dos olhares da sociedade, esta ainda lhe era uma ameaça. Ao final da narrativa, Lúcia passa a ter uma vida recatada na companhia de sua irmã Ana e sustentando um amor fraternal por Paulo, mas a ideologia que vigorava na época, não lhe permitia um final feliz. Em seus momentos finais, Lúcia sucumbe levando consigo um filho que jamais poderia ser gerado. $\mathrm{O}$ amor não poderia consumar-se, não para ela. Mas sua redenção estava ali, na morte, eis, então, suas últimas palavras a Paulo:

- Tu me purificaste ungindo-me com os teus lábios. Tu me santificaste com o teu primeiro olhar! Nesse momento Deus sorriu e o consórcio de nossas almas se fez no seio do Criador. Fui tua esposa no céu! E contudo essa palavra divina do amor, minha boca não a devia profanar, enquanto viva. Ela será meu último suspiro. [...] - Recebeme... Paulo!... (Idem, 150)

A morte era o castigo e a salvação de Lúcia. A ideia é "o vício castigado pelo próprio vício", com propõe o próprio Alencar. Apesar de ter se redimido dos seus erros, Lúcia ainda é a representação do desvio moral, daquilo que deve ser evitado e que é rejeitado pelo regime patriarcal e por isso deve ser punida.

Não muito distante da personagem romântica, encontramos Lenita. O romance $A$ Carne, de Júlio Ribeiro, data de 1888 e também desperta no público um grande rebuliço 
e consternação. O romance evidencia na personagem Helena, ou Lenita, forte sensualidade e desejo sexual. Construída dentro dos ideais da estética naturalista, a obra ilustra com teor científico a visão que a medicina e a psicologia assumiam sobre a sexualidade feminina. Conhecida como uma obra obscena, A Carne

\begin{abstract}
foi, por muito tempo, considerada pornográfica e perigosa à formação moral das crianças, adolescentes e mulheres, tida como inferior por grande parte da crítica, esteticamente, mas, principalmente, porque tratava de temas vistos como perigosos e infames. A frase mais famosa e significativa que define a polêmica da obra foi dada pelo crítico José Veríssimo: "é um parto monstruoso de um cérebro artisticamente efêmero". O conflito que surge com a publicação se dá porque a obra contém temas que são perturbadores das convenções sociais e tem marcas de uma ambivalência, já que, ao mesmo tempo que é repelido, é alvo de grande curiosidade, alcançando alto número de publicações, além de ser um dos livros mais discutidos do país pela forma como suscita diferenças de opiniões. (CABRERA, 2010, p.9)
\end{abstract}

Diferente de Lúcia, Lenita, do romance A Carne, era uma "moça de família". Fora criada pelo pai, e este cuidou em dar-lhe uma educação diferenciada daquela que era dirigida às demais moças. Ao invés de bastar-lhe a ligeira alfabetização e a educação doméstica, Lenita recebeu instrução de ciências, matemática, física, artes, línguas estrangeiras, etc.

Lenita tinha um comportamento diferenciado daquele que seria apropriado, estava sempre procurando se instruir ainda mais, mergulhada em livros densos, não se interessava pelo casamento. Não era vulgar, ao contrário, sempre parecia recatada, mas seus conhecimentos e beleza a faziam superior aos homens:

E não tinha nada de pretensiosa, bas bleu: modesta, retraída mesmo, nos bailes, nas reuniões em que não de raro se achava, ela sabia rodear-se de uma como aura de simpatia escondendo com arte infinita a sua imensa superioridade" (Idem, Ibidem).

Percebemos, a partir destas informações, que Lenita caracteriza como uma transgressora, não apenas pelo seu comportamento sexual, sua educação já a desvia do perfil idealizado numa época em que se acreditava que a mulher era controlada pelo útero e que instrução demais poderia desvirtuá-la.

Com a morte do pai, Lenita vai morar na fazenda do Coronel Barbosa, aonde sofre a primeira crise histérica, a partir de então ela sofre uma ligeira mudança:

E Lenita sentia-se outra, feminizava-se. Não tinha mais gostos viris de outros tempos, perdera a sede de ciência: de entre os livros que trouxera procurava os mais sentimentais. Releu Paulo e Virgínia, o livro quarto da Eneida, o sétimo do Telêmaco. A fome picaresca de Lazarilho de Tortnes fê-la chorar.

Tinha uma vontade esquisita de dedicar-se a quem quer que fosse, de sofrer por um doente, por um inválido. Por vezes lembrou-lhe que, se casasse, teria filhos, criancinhas que dependessem de seus carinhos, de sua solicitude, de seu leite. E achava possível o casamento. (Idem, p.20). 
Esta mudança começa a intensificar-se, Lenita começa a revelar sua sexualidade, primeiro ao contemplar a estátua de Agasias, a mesma que já havia observado tantas vezes, mas que agora provocava-lhe uma sensação até então desconhecida:

Sentia-se fraca e orgulhava-se de sua fraqueza. Atormentava-a um desejo de coisas desconhecidas, indefinido, vago, mas imperioso, mordente. Antolhava-se-lhe que havia de ter gozo infinito se toda a força do gladiador se desencadeasse contra ela, pisando-a, machucando-a, triturando-a, fazendo-a em pedaços.

E tinha ímpetos de comer de beijos as formas masculinas estereotipadas no bronze. Queria abraçar-se, queria confundir-se com elas. (Idem, p.21).

A personagem toma, então, conhecimento de que o que se manifestava nela não era nada mais que o instinto fisiológico da fêmea que necessita de um macho. Sente-se envergonhada, lembrando que desejos desta espécie eram terrivelmente repreendidos pela moral e pela religião, é algo animalesco, por isso Lenita sente nojo de si, como podemos verificar na seguinte passagem: "sentir-se ferida pelo aguilhão da carne, espolinhar-se nas concupiscências do cio, como uma negra boçal, como uma cabra, como um animal qualquer... era a suprema humilhação." (Idem, Ibidem). Entretanto, este desejo a acompanhará permanentemente, segue-se então uma nova crise histérica, na qual, após um delírio erótico em que a estátua do digladiador toma forma humana e a possui, Lenita sofre "estremeções de prazer" e desmaia em convulsão.

A moça recupera a saúde e curiosidade pelos assuntos masculinos, como a as atividades dos engenhos, frequenta-os junto do coronel e quer-se manter à par dos negócios. Contudo, ao saber da chegada do filho do fazendeiro, deixa-se conduzir pelo desejo latente que nela se desenvolve. Idealiza e deseja o filho do coronel, mesmo sem conhecê-lo, pensa nele constantemente e um novo comportamento se instaura na personagem: o sadismo. Ela se torna cruel, sente prazer em provocar a dor, beliscava as escravas, torturava animais, comprazia-se no açoitamento que castigava os negros.

Por vezes, Lenita observava estas mudanças que lhe iam acontecendo, principalmente os desejos frêmitos que sentia por Manuel Barbosa, o filho do coronel. Analisava sua situação e ora concluía que era um estado patológico que a consumia, ora o interpretava como um estado fisiológico, "era a voz da carne a exigir dela o seu tributo de amor, a reclamar o seu contingente de fecundidade para a grande obra de perpetuação da espécie". (Idem, p.40), mas isso não afastava dela a ideia de que seus desejos eram passíveis de punição:

E lembrava-lhe a ninfomania, a satiríase, esses horrores com que a natureza se vinga de fêmeas e machos que lhe violam as leis, guardando uma castidade impossível; lembrava-lhe o horror sagrado aos povos da Grécia e Roma inspiravam esses castigos de Vênus. (Idem, Ibidem, grifo do autor.)

Um pensamento comum na época, um momento em que não havia espaço para a sexualidade feminina e esta era considerada responsável por diversas enfermidades. Mas as mudanças que se operavam em Lenita afastam o possível assombro que acompanha o conceito patológico para o que vivia. Lenita rompe, então, com a ordem 
social, questiona a validade do casamento, uma vez que este era apenas um vínculo social de motivação religiosa, moral e econômica, sendo jovem, bela, rica e emancipada, poderia facilmente encontrar pretendentes, tantos quantos já dispensara. Entretanto, seu objetivo em procurar um esposo não se destina a procriação e manutenção da família, Lenita quer se saciar sexualmente: “- Se era a necessidade orgânica, genésica de um homem que a torturava, por que não escolher de entre mil um marido forte, nervoso, potente, capaz de satisfazê-la, capaz de sacia-la?” (Idem, p.42), e vai mais além, assume uma certa virilidade e critica a moralidade social:

E se um lhe não bastasse, por que não conculcar preconceitos ridículos, por que não
tomar dez, vinte, cem amantes, que lhe matassem o desejo, que lhe fatigassem o
organismo? Que lhe importava a ela a sociedade e as suas estúpidas convenções de
moral? (Idem, Ibidem)

Teria amantes, por que não? Que lhe importavam a ela as murmurações, os diz-que-dizque da sociedade brasileira, hipócrita, maldizente. Era moça, sensual, rica - gozava. Escandalizavam-se, pois que se escandalizassem. Depois, quando ficasse velha, quando se quisesse aburguesar, viver como toda a gente, casar-se-ia. Era tão fácil, tinha dinheiro, não lhe haviam de faltar titulares, homens formados que se submetessem ao jugo uxório que lhe aprouvesse a ela impor-lhes. Era pedir por boca, era só escolher. (Idem, p.44)

Lenita, então, rompe de vez com o perfil traçado pela ideologia do século XIX. Além de sua educação e ideias masculinizadas, ela também se deixa envolver por um desejo que é considerado natural apenas aos homens. Não demora, Lenita e Barbosa começam a se envolver afetivamente, o que poderia até ser confundido com o amor romântico, mas o que prevalece é o desejo: Lenita deseja Barbosa e ele a deseja. Mesmo diante dos empecilhos que tornam este relacionamento impossível, é agora Barbosa quem critica o matrimônio, para ele o casamento também é uma instituição falida, hipócrita e imoral.

Barbosa é casado com uma francesa, embora esteja divorciado, casar com Lenita é impossível, mesmo ele esteja completamente tentado pela moça, tenta afastá-la do pensamento. Há, princípio, em Barbosa o pudor que falta em Lenita, e novamente rompendo com os padrões e infringindo regras, é ela quem o procura em seu quarto e procura saciar suas ânsias, num período em que é proibido às mulheres tomarem iniciativa e demonstrar seus desejos, Lenita não só controla a situação como procura satisfazer a si mesma:

Lenita perdeu completamente a cabeça, entrou: em bicos de pés, sem fazer rumor, escorregando, deslizando, como um fantasma, abeirou-se da cama de Barbosa. (...) Lenita agarrou-se a Barbosa, cingi-o, enlaçou-o com os braços, com as pernas, como um polvo que aferra a preia; com a boca aberta, arquejante, úmida, procurou-lhe a boca; refinada instintivamente em sensualidade, mordeu-lhe os lábios, beijou-lhe a superfície polida dos dentes, sugou-lhe a língua... (Idem, p. 111-113)

Enquanto que Barbosa, que num primeiro momento considerara monstruosa a presença da moça em seu quarto e em trajes de dormir, se deixa dominar pelos próprios 
instintos. Um relacionamento sem pudor se estabeleceu entre os dois. O relacionamento dura até o momento em Lenita descobre durante a ausência do amante, entre os objetos de Barbosa, lembranças de outras mulheres com quem ele se relacionara. Enciumada e decepcionada, resolve voltar para São Paulo, sentia-se castigada e considerava isso justo, olhando para si com os olhos da sociedade, via o quanto descera em seus princípios morais. Neste momento, assume que o que sentira por ele não era natural, não era saudável, era um desequilíbrio orgânico, uma nevrose.

Numa carta revela a Barbosa que está grávida e que vai casar-se, pois precisa de um pai oficial para seu filho. Observemos que nesta obra, a protagonista não teve um fim trágico como em Lucíola, mas isto se explica pelos próprios conceitos dos movimentos literários em que as obras se encaixam, enquanto que no Romantismo prima-se pelo sentimentalismo e idealização de comportamentos, o Naturalismo foge dessa hipocrisia, o objetivo é revelar o verdadeiro comportamento da sociedade à luz da lógica e da ciência. Lenita refletira sobre sua situação, ela é rica, sabendo ocultar seu passado, poderá ser tão respeitada quanto às pudicas senhoras. Com um casamento bem administrado, a moral pública de Lenita está ilesa. Entretanto, o próprio Barbosa em vista do que acontecia, apesar de ser cúmplice e de compartilhar dos prazeres carnais de Lenita, revela o olhar daquela sociedade perante a personagem, ao chamar-lhe furiosamente: “- Rameira! Prostituta vil!” (Idem, p. 127).

Assim como em Lucíola, no romance A Carne, a ideia da sexualidade feminina é recriminada. O tempo todo se torna evidente que o que Lenita sente é algo monstruoso, doentio, tanto ela quanto Barbosa reconhecem neste comportamento pervertido um desvio da moral, o que a faz inferior às demais mulheres que se resguardam desses “instintos animais". Lenita não recebe um castigo trágico como o de Lúcia, mas é obrigada a se ajustar àquela sociedade, para que continue fazendo parte dela.

Esta sociedade, entretanto, estava em plena mudança. Os estudos científicos avançavam, a economia assumia novas perspectivas e a política se transformava, as pessoas também experimentavam novas necessidades, ou assumiam novas atitudes em relação às antigas necessidades. Ao longo do século XX, as mudanças chegavam de forma efusiva, provocando ao mesmo tempo o choque em alguns e a satisfação em outros. Desde o século anterior já se ensaiava uma vida pública, entre os bailes e os convívios sociais, o século XX leva as pessoas para as ruas, para os espetáculos, para o cinema, este novo modo de viver implicava na exposição física. Novos conceitos de sensualidade se formulavam: "Há quem diga que o século XX inventou o corpo! Corpo novo e exibido. Mas, também, um corpo íntimo e sexuado que, lentamente, veria afrouxar as disciplinas do passado em benefício do prazer" (DEL PRIORI, 2011, p. 76).

Ainda como alerta sobre os riscos que uma sexualidade ativa poderia oferecer às mulheres, a prática de esportes e a dança eram indicadas pelos médicos, em vista de garantir uma vida saudável, e para isto eram necessários trajes adequados que promovessem a liberdade do corpo. Assim, aos poucos, os espartilhos e vestidos volumosos iam sendo substituídos por roupas mais leves. Durante a década de 1920 surgiu a lingerie, e esta indumentária feita de rendas e frufrus acabava por chamar a 
atenção dos homens para a sensualidade da própria esposa, a vida conjugal ganhava poesia e graça:

Graças à lingerie, o corpo passou a ser um objeto estético, fonte de desejo e contemplação, não só o santuário das virtudes vitorianas e hipocrisia. $\mathrm{O}$ pudor começava a recuar. Inculcado desde a primeira infância e reforçado nas meninas durante a adolescência, doravante ele iria se articular com as exigências do casamento. Casais se envolviam cada vez menos para atender aos interesses familiares e cada vez mais por amor. O trunfo do encanto físico e da sedução passava a contar. E o refinamento da sugestão introduzia-se na intimidade de homens e mulheres. (Idem, p. 78)

Espartilhos, meias de seda, ligas e cintas se tornam símbolos de erotismo. Acompanharemos, neste século, o processo de erotização do corpo feminino, promovido pelas revistas de moda e pelos espetáculos públicos como o teatro e o carnaval. Um novo padrão de beleza estabelecia-se, buscavam-se corpos magros e rostos rosados pelo ar livre, as mulheres inspiravam-se nas celebridades.

As mudanças sociais, políticas e culturais implantadas depois da República tornaram possível um novo olhar sobre a sexualidade e, sobretudo, sobre a mulher. $\mathrm{O}$ corpo ganhou movimento e liberdade, era uma questão de saúde e também de vaidade. A pesquisa de Del Priori (2011) mostra que a concepção de espaço também se transforma, o ambiente urbano torna-se popular e a burguesia ascendente quer usufruir deste espaço e das paisagens e lugares reservados ao lazer, banhos de mar e de sol eram sinônimos de vida saudável.

No entanto, o acontecimento que virá a transformar de vez as relações entre os indivíduos e a sexualidade, principalmente a sexualidade feminina, será a Primeira Guerra Mundial, na qual as mulheres também trabalharam, substituíram os maridos e irmãos nas indústrias, enquanto estes estavam em campo de batalha. $\mathrm{O}$ trabalho braçal exigia roupas mais cômodas: os braços vieram à mostra, os vestidos se tornaram menos volumosos, os espartilhos foram aposentados da indumentária social. Apesar de uma importância e necessidade sociocultural, esta transformação na vestimenta e papel social da mulher tornou-se basilar para as revoluções que viriam pela frente e que colocariam o gênero feminino em outro patamar, pois a partir deste momento, começou-se a se repensar acerca as noções de liberdade e de moral. O corpo sensualizou-se, não o corpo da prostituta (pois este já levava consigo este atributo), mas o corpo das esposas, estas saíram da sacralização e tornaram-se humanas e vaidosas.

Entretanto, havia uma deficiência em toda essa transformação, pelo menos durante a primeira metade do século, pois enquanto o corpo se sofisticava, mantinha-se a ignorância sobre a sexualidade feminina. Entre as mulheres esse assunto ainda era um tabu, usavam eufemismos para falar sobre menstruação, não se falava sobre sexo, as noivas casavam-se despreparadas para a noite de núpcias, a virgindade continuava obrigatória. Sobretudo, permanecia ainda um abismo entre a "mulher da vida" e a "mulher de família", aconselhava-se aos homens que evitassem diante da esposa o comportamento sexual que tinham entre as prostitutas, pois repeti-los com a esposa equivaleria a insultá-la, ofendê-la e até mesmo, prostituí-la. Quanto às mulheres, estas deviam ser comedidas em sua vida sexual, pois os excessos poderiam desgastá-las e 
provocar inúmeras doenças físicas e nervosas, Como afirma Del Priori (2011, p. 85), a mulher deveria se contentar com aquilo que o marido lhe oferecia, jamais exigir mais que isso, e também era seu dever cuidar para controlar os impulsos sexuais do marido. Durante este início de século ainda era preciso manter o decoro dentro do casamento:

Pudor e recato, sobretudo no quarto, eram sinônimos de distinção. Só mulheres de reputação duvidosa tomavam iniciativa. Quanto às centenas de milhares de relações vividas fora do casamento, estas passavam a ser consideradas "imorais". Membros das camadas mais baixas da população, como ex-escravos, operários, imigrantes pobres, negros e mulatos que vivessem em amancebamentos, concubinatos ou ligações consensuais, eram acusados de "conduta indecente". (Idem, p. 86)

Por outro lado, havia outra forma de pensar proeminente, de acordo com Del Priore (2011), sexólogos como o australiano Havellock Ellis, defensores do autoerotismo e críticos da repressão, estavam sendo traduzidos no mundo inteiro e divulgavam os benefícios do sexo dentro do casamento, para eles, sexo não era apenas um instinto de reprodução, e sim um reflexo do afeto entre o casal. Outro estudioso, Wilhelm Reich, realiza uma pesquisa entre 1927 e 1935 sobre a "potência orgástica", resultado na obra A Revolução Sexual, que só seria traduzida para no Brasil na década de 1940, esta seria uma grande colaboração para tirar do silenciamento secular a questão da sexualidade feminina.

O resultado desse novo olhar sobre a mulher pode ser muito bem observado na década de 1950, que apesar das muitas regras sociais e morais ainda vigorarem, as mulheres começam a ser flagradas nas ruas bebendo, fumando e beijando homens com quem não têm nenhum compromisso. Muitas abriam mão, inclusive, da virgindade e do casamento. E o carnaval era um momento singular em que até mesmo as "moças direitas" e as senhoras podiam realizar suas fantasias:

O carnaval era visto como uma festa perigosa, depravada, na qual as "ligações mais secretas transparecem, e que a virgindade é dúbia e inútil, a honra, uma caceteação, o bom senso, uma fadiga". O desejo, sobretudo o feminino, engessado pelos bons costumes durante do ano, explodia nas fantasias e comportamentos espontâneos. Era "sem-vergonhismo" puro, no entender de alguns. Caminhada para a liberdade, no de outros. (Idem, p. 106)

Aos poucos a ideia de família também foi se modificando, ainda se exigia a submissão da esposa, mas agora o laço matrimonial de realizava por questões afetivas e esta aproximação entre marido e esposa levanta questionamentos sobre suas relações conjugais. Entre os anos 60 e 70 eclode, finalmente, a "revolução sexual", isto significou uma busca pela satisfação pessoal, a sexualidade deixa de ser um tabu e começa a fazer parte da vida das pessoas como algo necessário à saúde e ao bem estar: "o direito ao prazer tornou-se norma. E norma cada vez mais interiorizada. Apenas conformando-se a essa regra seria possível sentir-se feliz, alegre e saudável." (Idem, p. 124). Pode-se, enfim, remodelar o conceito social de homem e mulher: 
Elas começavam a poder escolher entre desobedecer às normas sociais, parentais e familiares. Ficava longe o tempo em que os maridos davam ordens às esposas, como se fossem seus donos. Um marido violento não era mais o dono de ninguém, mas apenas um homem bruto. Uma vez acabado o amor, muitos casais buscavam a separação. Outros faziam o mais fácil: tinham um "caso". E, desse ponto de vista, o adultério feminino era uma saída possível para quem ousasse romper a aliança. (Idem, p. 125)

Ao longo da década de 70, movimentos em apoio às minorias e em defesa das mulheres começam a ganhar forma. A sexualidade se torna algo natural, normal e saudável. A pílula contraceptiva fora aceita tanto pelos homens quanto pelas mulheres, pelo conforto e segurança que ela permitia. $\mathrm{O}$ orgasmo simultâneo era o que media a qualidade das relações. Pode-se dizer então que, finalmente, a sexualidade feminina fora reconhecida, a mulher era tão capaz quanto o homem de sentir prazer no ato sexual, sem que isso que comprometesse a saúde.

O prazer, o erotismo e a liberdade caminham juntos na obra Contos d'escárnio Textos grotescos, de Hilda Hilst, uma obra considerada pornográfica pela crítica. Já nos deparamos então com dois pontos importantes que evidenciam a distância que já se toma das obras analisadas anteriormente: temos uma escritora desenvolvendo, num vocabulário grosseiro, as aventuras sexuais de um escritor, algo singular e imoral para o século XIX e meados do século XX, mas apenas provocativo para a década de 1990. O intuito na obra não é evidenciar a questão da sexualidade, e sim, através da pornografia, criticar o mercado editorial da época:

Hilda investe na pura Pornocracia para tentar furar o muro de silêncio que a envolve todos estes anos. Acusando que o autor nacional só é levado a sério quando dá todos os nomes às coisas que ficam da cintura para baixo. (MEDEIROS, 1991, p.58)

Hilda Hilst recebeu duras críticas questionando a qualidade de sua obra, mas isso se devia mais ao choque provocado pela linguagem e pelo grotesco das cenas narradas, do que ao abalo moral que o livro poderia causar. O pesquisador Alcir Pécora (apud FRANCISCO, 2007) afirma: "Não é pornográfica a pornografia de Hilda Hilst". Pois, para o pesquisador, a obra contraria a lógica da literatura pornográfica comercial, apesar da crueza de sua escrita, ela não consegue provocar a excitação do leitor. A narrativa é, deveras, singular: Crasso, o personagem narrador, de maneira irreverente, nos conduz em suas memórias, por vezes muda-se o narrador e novas cenas são acrescentadas à narrativa. Os acontecimentos narrados não seguem uma ordem linear e tampouco têm uma relação entre si, além de que a narrativa não apresenta desfecho.

Em inúmeros aspectos ela se diferencia das obras romântica e naturalista já analisadas, contudo, o que nos interessa neste momento é a personagem Clódia, ela não é a protagonista, é uma das amantes de Crasso, mas que acaba ganhando certa relevância na obra devido seu relacionamento com o narrador. Clódia carrega em si o fruto de todas as mudanças operadas ao longo do século, sua sexualidade não é julgada ou questionada, ela simplesmente é e se realiza. Crasso a encontra pela primeira vez na igreja, era uma mulher muito bonita, segundo o narrador a ponto de causar-lhe excitação: "Estava a ponto até de falar com o pulha do padre sobre esses afrescalhados 
pensamentos quando uma dona morena, alta, estreita de quadris, mas de bunda perfeita, ajoelhou-se um tiquinho mais à frente." (HILST, 2002, p. 32). A mulher chorava, Crasso aproximou-se dela e começaram a conversar, nisto ela lhe revela o motivo da tristeza, sua amante embarcara em lua-de-mel com o marido e a abandonara. A questão do homossexualismo aqui é apenas citada, não se torna um fato relevante, apesar de que até hoje ainda há certo preconceito moral em relação a isso, a época de produção da obra já era tempo de militância em prol dos homossexuais, e isto tanto não abala o narrador, como ele continua atraído por Clódia.

Outro fato interessante desta personagem: ela exercia uma profissão, era museóloga. No decurso do século XX, discussões e lutas foram travadas para que fosse possível a admissão das mulheres na academia. Durante muito tempo, sustentou-se a ideia de que havia empregos exclusivamente femininos e outros nos quais as mulheres não poderiam ser admitidas. Às mulheres foram negados certos conhecimentos, por serem consideradas intelectualmente inferiores aos homens e incapazes de compreender a arte e as ciências. Encontramos então, neste fim de século, uma mulher exercendo uma profissão de cunho intelectual e que necessita de profundo conhecimento técnico e teórico das artes. Ainda mais, Clódia também domina a arte na prática, ela é pintora, e sua inspiração é um tanto inusitada:_Clódia pinta vaginas.

Depois desse encontro, Crasso torna-se amante de Clódia e ele dá-lhe a ideia de também pintar pênis, e ela acaba tomando este exercício como uma nova ocupação, "pintou paus de todos os tamanhos e expressões" (Idem, p. 46), gostou tanto da nova predileção que um dia fora presa ao fazer um mendigo mostrar o pênis na praça para que ela pudesse pintar, e de tanto insistir com os guardas para que eles lhe mostrassem seus pênis, eles a mandaram para um hospício, onde ela recolhera pequenas narrações e poemas eróticos. Clódia era extravagante, mas era uma mulher livre dos ditames morais que reprimiam seu direito ao prazer. Através da representação de Clódia, nos deparamos com um novo perfil do feminino, não mais a mulher frágil, submissa e destinada à maternidade. A personagem é uma representação da mulher moderna, que não precisa mais do casamento, uma mulher que pode ter sua própria carreira, que pode ter quantos parceiros quiser sem sentir culpa, que pode expressar sua sexualidade.

\section{3) Considerações finais}

Entre a repreensão e a liberdade sexual, entre a sacralização e a erotização do corpo, há um muro que foi fendido a muito custo. Tabus foram rompidos para que um novo conceito de feminilidade e de masculinidade fosse construído. Talvez hoje pareça absurdo pensar que algo que para a sociedade do nosso século é tão comum e íntimo, já tenha sido questão do Estado e da igreja, mas além dos relatos históricos, podemos contar também com o registro literário, que nos permite reconhecer a transformação dos comportamentos e da ideologia.

As obras apresentadas em análise são apenas recortes deste intervalo de tempo no qual as transformações mais marcantes aconteceram. Cada uma gerou um impacto no público à sua maneira, seja por uma temática considerada imoral, seja por uma linguagem mais crua e violenta. A transgressão nunca é vista com bons olhos por uma 
sociedade tradicional, tanto é que obras como Lucíola e A Carne chegaram a ser proibidas, e quando eram lidas, era por um público bem restrito. Até mesmo o romance de Hilda Hilst, que apesar de já aparecer numa época em que a pornografia era praticamente uma exigência do público, provocou certo estranhamento naqueles que já acompanhavam a trajetória da escritora.

Qualquer tipo de transgressão incomoda, e a transgressão do feminino entre os séculos XIX e XX foi uma polêmica que mobilizou a sociedade, a ciência e a religião. Entre os defensores dessas transformações e os defensores dos "bons costumes" o embate foi intenso. Entre mulheres prostituídas, pervertidas e modernas há camadas de história, de rejeição, preconceito, ideologias, e claro, de desejo e necessidade de transformação.

\section{Referências}

ALENCAR, José de. Lucíola. São Paulo: Ciranda Cultural, 2009.

1858.

“Defesa de As asas de um anjo". Diário do Rio de Janeiro de 23 de junho de

CABRERA, Lívia Maria Gonçalves. Da Fragilidade à Histeria: corpo e subjetividade femininos em A Carne (1888), de Júlio Ribeiro. Monografia (Bacharel e m Ciências Sociais) São Carlos: Universidade Federal de São Carlos, 2010.

DEL PRIORE, Mary. Histórias Íntimas: Sexualidade e erotismo na história do Brasil. São Paulo: Editora Planeta do Brasil, 2011.

DE MARCO, Valéria. O império da cortesã Lucíola: um perfil de Alencar. São Paulo: Martins Fontes, 1986.

FARIA, João Roberto. O teatro realista no Brasil: 1855-1865. São Paulo: Perspectiva: EdUSP, 1993.

FOUCAULT, Michel. História da sexualidade I: A vontade de saber. Rio de Janeiro: Editora Graal, 1988.

FRANCISCO, Ronnie. Na falha da gramática, a carne: a pornografia em Hilda Hilst. Dissertação (Mestrado em Estudos Literários). Belo Horizonte: Faculdade de Letras da UFMG, 2007.

HILST, Hilda. Contos D’escárnio - Textos Grotescos. São Paulo: Globo, 2002.

PINTO, Maria Cecília Queiroz de Moraes. Alencar e a França: perfis. São Paulo: Annablume, 1999.

RIBEIRO, Júlio. A carne. São Paulo: Martin Claret, 2002.

SILVA, Luciane Nunes da. O Conservatório Dramático Brasileiro e os ideais de arte, moralidade e civilidade no Século XIX. Universidade Federal Fluminense. 
Centro de Estudos Gerais. Instituto de Letras. Tese de Doutorado em Literatura Comparada, 2006. 